[King, D. (2004). The Quiet Crisis: International Students in New Zealand Secondary Schools. New Zealand Annual Review of Education, 13, 43-61]

\section{The Quiet Crisis: International Students in New Zealand Secondary Schools}

\section{DEB KING}

New Zealand schools can't survive and be effective institutions without the input from international students. And yes, that's mostly about money. (Weekend Herald, 2002, May 18)

\section{Abstract:}

Foreignfee-paying (international) students have been present in New Zealand secondary schools for over a decade. In recent years the number of such students has increased dramatically, and their distribution is not evenly spread across schools. The increase has led to a situation in which schools are relying on international student funding to meet budget requirements. This article presents the results of a small, sharply focused case-study, following a review of the policy issues and literature surrounding the international student presence in New Zealand. It concludes that increased monitoring and research is necessary to ensure that all students experience the maximum chance for success within the New Zealand system.

$\mathrm{T}$

he foreign fee-paying student market is currently estimated to be worth $\$ 1.7$ billion to the New Zealand economy, and that figure is rising every year as the number of international students continues to grow strongly (Ministry of Education, 2003). For example, since 1998, the Wellington region has experienced a total growth of 80 percent (Education Wellington International, 2003). In 2002, there were over 15,000 international students in 761 New Zealand secondary schools (Education Review Office, 2003). There is no doubt that foreign fee-paying students bring a wealth of positive cultural and social experiences to domestic New Zealand students, but the costs and benefits of fee-paying or international students still have to be

\section{Deb King}

measured. Many schools and tertiary institutions are now reliant on the funding that international students provide to top up their budgets and keep them running.

In the light of this growth, there are increasing calls for the New Zealand Government and secondary schools themselves to consider the impact of the rapid internationalisation of New Zealand secondary education. Studies by Kennedy and Dewars (1997), Ward (2001), and the Ministry of Education (2001) conclude that the effect this large increase in international students is having on the domestic or "kiwi" student within the classroom needs closer examination.

This article begins by briefly considering the education reforms that began in the late 1980s with the Picot Report (Department of Education, 1988a) and the subsequent Tomorrow's Schools document (Department of Education, 1988b). The consequences of the resulting "community empowerment" (Fiske \& Ladd, 2000, p. 57) and the promotion of a fundamental business approach to school management will then be discussed in relation to their impact on international and domestic students in the classroom. This is followed by an examination of the sparse current literature on the topic, and the presentation of a small, sharply-focussed Wellington-based case study.

The case-study was completed by the author to determine the perceived effect that international students had on domestic students at the secondary level, and the level of support available for international students to ease this impact.

Based on the existing literature and the results of the case study, the suggestion is made that, if current trends continue, the "business" approach to education in many secondary (and an increasing number of primary) schools will result in schools requiring international students to ensure they can meet the demands of their budgets. This may result in schools having to sideline the educational needs of domestic or resident students to ensure international student numbers are maintained and demands met. It will be argued that current policies and the economic marketplace emphasis on education at secondary level have resulted in the New Zealand Ministry of Education beginning to "abdicate its responsibility for State-funded education" (Ross, 2002, p. 9).

Recent policy changes implemented by the Ministry of Education include the Code of Practice for the Pastoral Care of International Students (Ministry of Education, 2002a). This attempt to monitor the pastoral 
care of fee-paying students has addressed some of the needs of international students. However, it does not ensure that schools take due consideration of the numbers of international students within their classrooms, nor guarantee that they provide adequate support and space for all students. It will be argued that the Code of Practice is necessary if fee-paying students are to leave New Zealand having had a positive experience of the culture and the education system. But it is not the complete answer. The article will conclude that for New Zealand to become a leader in international education, closer examination of the experiences of both international and domestic students must take place. In addition, teaching practices within classrooms must be carefully examined to determine the appropriate methods of teaching a combination of international and domestic students within our education system.

\section{Specific Policy Questions}

Two particular questions need answering, and these will be considered in turn:

The extent of internationalisation: Has the trend gone too far and encouraged schools to make money at the expense of educating New Zealanders?

The 1989 Education Act and Tomorrow's Schools government policies were written in an attempt to meet social and economic needs addressed by the Picot report in 1988. In a press statement, the Minister of Education, Rt. Hon. David Lange, said "Tomorrow's Schools will need to be more dynamic - able to respond and adapt quickly both to the needs of their communities and to the pace of change in society" (Office of the Minister of Education, 1988, p. 1). As a result of this increased control of communities over their schools, the reforms promoted a degree of choice that had not previously existed. Fiske and Ladd argue that this transfer of authority to parents was a "logical extension of a long-standing democratic-popularist heritage" (2000, p. 37). This sprang from the new mandate to allow communities to determine the specific needs of their own schools. The authors suggest that this was part of the reason why schools were given some control. The other "improvement" was an emphasis on the "managerialbusiness" method of keeping decision-making close to where the decisions are implemented. The change also allowed schools the freedom to enrol international students who would pay to attend a school in New Zealand.

The 1991 Education Amendment Act passed by the new National government resulted in a system that was built on the idea of "choice" encapsulated in the 1989 reforms, and resulted in the abolition of zoning. This in effect gave domestic parents the ultimate choice where to send their child to school. Fiske and Ladd (p. 62) argue that the resulting competitive environment was the residual strand from the Tomorrow's Schools reforms, stressing that schools will function best when competing for "clients". They also suggest that the 1991 Education Amendment Act changed the focus of Tomorrow's Schools from "community participation in governance" to "an educational marketplace" (p. 180).

By 2000, the 1991 policy on zoning had been modified by the Education Standards Act, which stated that schools must now legally be required to accept students from within their zone. Whilst attempting to solve some of the problems with schools "marketing" themselves, this policy generated some concern, as there were many families who wanted to, but could not afford to, move into areas where "successful" schools had set their boundaries - high decile schools. These schools are situated in areas where census records show high average incomes, as opposed to low decile areas where parents generally earn less. Schools in New Zealand are allocated funds on this basis, with the low decile schools being allocated more money per student, on the basis of a compensatory weighting formula.

International students have now joined the education market place in New Zealand en masse, although their distribution is variable (Ministry of Education, 2002b). Auckland dominates, enrolling over half of the international intake, whilst "one third of New Zealand secondary schools have no international students" (Ministry of Education, 2001, p. 22). Urban middle-to-high decile schools have many more international students than low decile or rural schools, as they have the opportunity to market themselves and their achievements more successfully. Low decile schools generally have "less preparedness to enter the market" (p. 25).

With less funding per student from the Government, the upper decile schools must strive to offer a broad, well resourced programme to ensure domestic students continue to enrol. The revenue gathered from international students is essential in keeping such schools 
functioning with resources that parents find appealing. Therefore, despite the funding differential from the Government in favour of low decile schools, the substantial amount of money earned by upper decile schools from their international students has now created an imbalance in the facilities and resources they can offer, and it is in these schools that international student numbers are increasing dramatically every year.

In 2001, nearly a third of all international students at secondary school were in the 48 decile 10 schools, with an average number of 61 students per school. In comparison, only five of the 33 decile 1 schools had any international students at all (Ministry of Education, 2002b, p. 17). Fiske and Ladd (2000) suggest that this market-driven view of education has placed low decile and rural schools in a harder position when it comes to paying their bills. Notwithstanding the current "zoning" policy by which students are required to attend their local school, all schools are now competing for both domestic and international fee-paying students, and some schools attract neither.

\section{- Are the needs of domestic New Zealand students in secondary} schools being sidelined by current policy?

Whether international students should be attending New Zealand schools is a very important question that needs to be considered by all secondary schools, on both an individual and a national level. In identifying the costs and benefits of our international programmes, we need to look beyond the international students to the domestic students, as the primary role of education in New Zealand must be to educate New Zealanders. Any institution contemplating entering the international market needs to consider carefully the benefits to domestic students (Ministry of Education, 2001), as the 1989 Education Act states that all of the costs associated with international students must be recovered by the institution. Since its passing, there has arisen a perception that fee-paying students are doing more than this, and now funding the core requirements of schools, rather than being the "icing on the education cake" (Ross, 2002, p. 9).

The Education Review Office has indicated that this increasing reliance on income from fee-paying students is worthy of further investigation. It proposes to determine "the extent to which schools are becoming dependent on income from FFPS (foreign fee paying students) and the nature of the expenditure of this income" (Education
Review Office, 2003, p. 31). In addition, a recent review of the Code of Practice recorded a growing clamour within the education sector, namely, that "central funding is increasingly inadequate" (p. 31).

There are few figures available as to the exact disposable income that international students are bringing into individual schools. However, the majority of fee-paying students in New Zealand secondary schools pay $\$ 10,000$ or more annually for tuition fees. Given this figure, it can then be surmised that with an average of 61 students each (Ministry of Education, 2002b, p. 17), decile 10 schools have around $\$ 610,000$ in additional funds at their disposal, whilst decile 1 schools largely miss out on this extra resourcing. Obviously there are costs associated with international students, but it is clear that the additional funding difference is significant. Add to this the fact that the education market is volatile (p. 10), and there is a grave concern that many schools and staff would not continue to function as they do should the international student funds disappear. There are currently more than 10,000 New Zealanders employed as a result of the international industry (New Zealand International Education Marketing Network, 2002, p. 20), so any drop in student numbers could also have a significant impact on job security and the economy as a whole. Marilyn Davies, Executive Director of Education Wellington estimates that for "every 10 international students in New Zealand, one job is created" (Allen, 2004, p. 5).

Further, there have been few attempts by the Ministry of Education to gauge the impact that international students are having on domestic students. Notably, the study by Ward (2001) and the analysis from the Education Review Office (2003) have drawn some interesting conclusions. Ward states that almost all available research is gathered from the international student perspective. Yet, increasingly, the proposed benefits of having international students are being questioned by those involved. Ward suggests that much of the evidence that international students bring a positive mix of cultural interaction is anecdotal. She also observes that interactions between international and domestic students occur infrequently, and argues that schools must provide programmes to promote interaction and friendships between these students.

The Education Review Office recently concluded that foreign fee-paying students "were not found to have a negative impact on the provision of education to domestic students." They did, however, 
suggest that schools need to consider that enrolments "do not surpass school capacity" (2003, p. 2).

Interestingly, the cover page of the Education Gazette of February 11, 2002 featured 13 students from different countries holding their respective flags with the headline "International Business". This lead article in the main teaching gazette for all sectors of state education in New Zealand explains a number of the key issues faced by secondary schools. One of the most worrying is the impact international students are having on the domestic student. Many classes include eight or more international students who have very different needs from those of the domestic student. Frequently, the international students require help with vocabulary, and they are less experienced at handling questions or activities that are perceived by teachers in New Zealand as important learning tools. As an example, many Chinese students are keen to study science at Bursary level, yet they have never conducted an experiment. Anomalies of this kind can result in significant changes in classroom dynamics, and place increasing demands on teacher time.

\section{Literature Review}

The research discussed in this article will focus on the policy changes that have allowed international students to enter New Zealand schools, and the consequences of their increasing numbers. The Government has a keen interest in maintaining the billion dollar industry of international education, yet the policy focus has been on ensuring the education "market" remains buoyant, rather than ensuring that quality education for domestic students is not compromised. There are clear indications in the literature of an awareness of these issues, yet only the research by Ward (2001) and the Education Review Office (2003) has examined them closely.

The Rt. Hon. Helen Clark, addressing the 2002 New Zealand International Education Conference, stated that the "challenge before us is not whether this sector can be grown, but how large it can be grown while retaining high quality standards" (Education New Zealand, 2002, p. 1). She went on to suggest that there were many intrinsic benefits to communities from their exposure to a wide range of cultural groups, something which the government wanted to encourage. Indeed "managing growth" was the focus for the whole conference, and rightly so. With a growth rate estimated by some to be over 40 percent per year in both tertiary and secondary sectors, the management of these huge increases must be a priority for the education institutions and for the government.

Ward (2001) has written extensively on international students, and provides a very strong case for more structured programmes to encourage integration. Commissioned by the Ministry of Education to research the impact of international education, she presents a number of issues not raised in other papers developed by the Ministry. These include: the need for integration programs, the need for teachers to adapt their teaching styles for international students, and the adaption necessary for whole schools to make international education work. Ward argues that the cultural interaction, deemed by the government to be the major positive impact on domestic students, does not occur if international and domestic students are not exposed to activities that are designed to "develop intercultural friendships" (p. 4). Any suggestion that interaction does occur is currently based more on "opinion than empirical evidence" (p. 38). In addition, domestic students are "largely uninterested in initiating contact with their international peers" (p. 3). She suggests that educators make very few efforts to change their activities to accommodate international students, and this makes their impact in the classroom much greater, in the long term. Furthermore, institutions that educate international students place heavy cost demands on support services.

Kennedy (1995) argues that international students have a significant impact on the New Zealand classroom. The Education Review Office $(2003$, p. 25) states that domestic students can feel "uncomfortable about being in classes where most students spoke Korean or Chinese." However, if teachers are prepared and supportive of the varying needs of the learner then positive friendships can develop.

Gamble and Reid suggest that international students are "keeping state schools afloat" (2002, p. B1). But most worryingly, the impact of these students on the domestic students is stated by several teachers in the article as being a consideration that only quality staffing, appropriate English language resources, and increased space can reduce. Unfortunately, the Government has yet to regulate these as requirements for state schools, concentrating primarily on the "high quality" and "high market value" of our education system overseas (Education New Zealand, 2002, p. 2). 
To many principals, it is obvious that the operations funding needed to run effective schools is lacking. Many complain that they are "funding the government with the cash they raise themselves" (Ross, 2002, p. 9). Former Prime Minister, Rt. Hon. David Lange was one of the key figures in the move towards international education, but he now suggests (p. 9) that "education is in jeopardy" for the domestic students, as the government funds less and less of the real costs of educating New Zealanders.

The Minister of Education, Trevor Mallard, has reacted to these comments, acknowledging that some schools have responded in "ad hoc ways and there hasn't been good discussion about capability and good practice" (p. 9). Interestingly, the Minister also stated that the government would not be restricting the numbers of students in schools, suggesting that "it was up to boards and principals to make sure they get the balance right", and further, that "foreign fees provide additional, not core income" (p. 9). It is this balance of numbers and growth that is the key consideration of the level of impact on domestic students. Jim Sinclair, a principal with a long history of involvement with international students in Auckland, suggests that "there is a limit to the number of international students you can have in a school and if you go beyond that limit it can have an adverse effect on the school community" (Education Gazette, February 11, 2002).

The Ministry of Education has released several documents addressing issues relating to numbers of international students and growth trends. The most interesting, Export Education - A Strategic Approach to Developing the Sector (Ministry of Education, 2001) reinforces the government's perspective on the importance of international students. There are several statements about export education being a key to the "knowledge nation" of New Zealand, and suggestions that there are more than financial benefits - knowledge and awareness of other cultures are regarded as essential for economic growth (p. 5). The Ministry also acknowledges in this document some of the issues regarding the number of students here- on several occasions reference is made to the effect of the "international market-place" on domestic students - "it [the government] must also ensure that benefits for domestic students, and New Zealand society as a whole, are realised" (p. 5), and "there is also a need to ensure that domestic students' interests are protected" (2001, p. 11). Further, some acknowledgment is made of issues arising from a lack of quality staff in the whole secondary sector, notably in English as a Second Language teaching However, what the paper does not do is provide schools with specific policies to ensure the needs of domestic students are treated as paramount.

Lester Taylor, Chief Executive of the Education New Zealand Trust, argues that self-management must take place, suggesting that the management of growth must come from a national body, rather than as a policy directive from the government. He acknowledges that the government will be "required ... to regulate if the industry does not do so itself" (Education New Zealand, 2001).

Neville Bennett (1998) suggests that many schools are not adapting to the needs of students (both domestic and international), and that Asian students come to New Zealand because it is good value for money, not because of the quality of its education system or the cultural experience.

\section{Policy Issues}

The number of international students in New Zealand schools has increased markedly over the last ten years. Since 1993 there has been a total growth of 507 percent (Ministry of Education, 2002b, p. 10). Schools are free to enrol as many students as they please, with no Government regulations in place to restrict numbers. The onus is on individual schools to decide how many international students they will enrol.

The Tomorrow's Schools reforms ensured that communities had control over their schools, and it is suggested by Olssen and Morris Matthews (1997) that these reforms resulted in a "market-ethos" of education (cited in Sullivan, 1999). At the same time, the Market Development Board was considering how it could increase foreign exchange earnings. In 1987, the Board recommended that for schools and universities to welcome international students, changes in policy would need to occur. By 1988, the Government had agreed to a "full cost-recovery fees policy" (Bennett, 1988, p. 25).

Importantly, the 1989 and 1990 Education Acts were passed to ensure that no domestic student could be displaced by an international student. There were initially a number of problems with the abuse of the Visa process, with private schools collapsing owing students money. This resulted in policies designed to protect the rights of students (notably and recently the 2002 Code of Practice). 
As a direct result of the liberal policies evident in New Zealand and worldwide, the 1990s began a period of policy change that directly impacted on education. Education became subject to the "user pays" principle, as tertiary students had much increased fees imposed on them. International students quickly became an important part of this development. Bennett (1998, p. 30) states that "the government contrasted the minimal fees it extracted from Kiwis with its full cost recovery from overseas students." In 1990, New Zealand followed other nations into the market for international students. The primary reason for this was economic, with a clear directive to create an export culture (Kennedy, 1995). The secondary reason was "globalisation" of education (Bennett, 1998). Education at the time was regarded as not doing enough to prepare New Zealanders for the global workforce. Some suggested that the education reforms of the late 1980s had resulted in inward-looking policies that did not prepare "citizens to participate internationally in their professions and businesses" (Bennett, 1998, p. 31).

In the mid 1990s, the then Minister of Education, Dr Lockwood Smith, strongly supported the internationalisation of education, stating that "overseas students were an excellent source of revenue" (p. 34). In 1994, the Burdon-Ross initiative was released, recognising the need to "strengthen New Zealand's international education performance" (Bennett, 1998, p. 32) and as a result the International Education Consultative Committee (IECC) was established to oversee the marketing and pastoral care of international students. Although support for international students existed from the Ministry at the time, the implications from Ministry documents are that the internationalisation of education arose primarily from individual institutions taking the initiative, and the government policies followed as the needs arose.

In 2000, the government funded the Asia-2000 Foundation of New Zealand to promote links with Asia, yet Bennett and others comment that at this time, there were still no policies in process to specifically promote internationalisation. However, the current support from the government for the development is clear, as the 2001 Export Education document indicates.

Since 1996 the government has had a voluntary code for international providers to follow. This is not compulsory, and the Code of Practice implemented by the Ministry of Education in 2002 is an attempt to address issues that have arisen with the home-stay care of international students. No provider of international education can operate after September 2002 without approval from the Ministry of Education. Schools must monitor the quality of home-stay care to ensure that students are placed with families who will care for them, not just take their money. As an extra precaution, all homestay parents must agree to a police check. The Code of Practice also strives to ensure that all students have some protection from institutions that do not deliver promises.

Education in New Zealand has changed markedly in the last 20 years. However, in secondary schools, it is suggested that changes in the classroom have been most prolific over the last two years. The arrival of international students accounts for some of that change. One of the key issues for schools is quality control - ensuring that all classrooms are offering students quality education that meets their learning needs. This is especially important if New Zealand is to remain in the international education market. Bennett (1998) argues that education is now a global commodity and this means that monitoring and assessing classroom practice is a major consideration for the future of the international market. Parents both in New Zealand and overseas require reassurance that the needs of their children are paramount within the classroom. Otherwise they will send them elsewhere.

\section{Case Study}

The motivation for carrying out this case study was the lack of New Zealand-based research that examined the impact of international students on domestic students, and considered the possible need for intervention at the school to encourage positive cross-cultural experiences for all students. Further, there were some indications that, at a senior level in particular, the nature of classroom interactions has changed over the last two years, as the numbers of international students have dramatically increased. The case study aimed to examine these issues and determine if students felt that there was a differentiation between the teaching of international and domestic students.

Key considerations included:

- The numbers of international students in individual classes;

- The interaction between international and domestic students; 
- The domestic students' perception of the impact international students have on them;

- The students' (both domestic and international) perception of the support provided by the school for international students.

The case study involved questioning 45 international students and 52 domestic students attending the co-educational secondary school where the author is the Dean of international students. Domestic students ranging from Year 9 to Year 12 completed the domestic student surveys. All had international students in their classes. International students ranging from 14 years old to 20 years old in mainstream schooling with some English as A Second Language support completed the international surveys.

There was only one variation in the questions asked of the two groups. Domestic students were asked what they thought the school offered international students, whilst international students were asked what they thought the school offered them.

\section{Results}

\section{The perspective of the domestic student}

Student numbers

The average size of the classes covered by the case study was 28. Most students stated that they had an average of two international students in their class at a junior level. This number rose to four in senior classes. Most felt that this was "just right".

Integration with international students

Three-fifths of "kiwi" students surveyed stated that they had an international student who was a friend. When asked to explain how they became friends comments included:

She needed some help with a few words and it just started from there.

I have met two international students who were put in my Vertical Form. They are both very friendly and easy to talk to except for some language barriers.

Of those who stated they did not have an international student as a friend, the comments included:

Because they always hang around in little groups of their own and they don't really want to be friends and aren't very friendly.
None of my friends were born out of NZ and they only have Maori/Samoan and English in them. I don't know why. I would if I had the chance to be a friend with a I.S.

Because I haven't got to know him much and he has his own friends.

These results support the findings of the Education Review Office (2003) that the existence of foreign, fee-paying students can allow friendships to develop across cultural boundaries, but that this was not a foregone conclusion for all students.

What do international students offer our school?

(Note that students could tick more than one of three boxes here.)

Of the 52 students:

- 39 students felt that international students bring a chance to learn about other cultures;

- 15 felt they bring "academic students";

- 20 thought they brought money for buildings.

Cultural inclusiveness

When asked whether teachers encouraged interaction between international and domestic students, 20 of the 52 students agreed that this was happening; 24 felt "neutral" about this statement; 30 said that teachers made a special effort to encourage international students; and 34 felt that international students take up too much of the teacher's time. This final figure (about two-thirds) reinforces the conclusions of the Education Review Office (2003) that a considerable number of domestic students felt that the pace of the class was slowed too much to cater for the international students.

\section{The perspective of the international student}

Student numbers

Most international students stated that they had an average of five or more other international students in their classes. Of the 45 students sampled, 27 felt that this was the "right number".

Integration with "kiwi" students

When asked if they were friends with "kiwi" students, 38 said "yes". When asked to explain how they became friends, comments included: I spoke with them and they invited me to do something after school. 
We had to talk to each other.

He like to listen to music, we often talk about pop music, and play soccer, basketball.

When I couldn't understand what teacher's saying, he always taught me kindly.

Those who stated that they did not have a "kiwi" friend included comments like:

Because I'm shy. So I can't say first.

The most important thing is they don't talk with me.

They don't talk to me. They do say hello but just that.

Why come to New Zealand?

(Note that the students could tick more than one of the three boxes.)

The results for this question were evenly spread throughout the three options:

- 27 said they came for a chance to learn about other cultures;

- 21 said they came for an academic education;

- 32 said they came for quality teaching.

This agrees with the conclusion of Ward (2001, p. 4) that for friendships to develop across boundaries, "situations must be structured to foster these processes."

Cultural inclusiveness

When asked if teachers encouraged interaction between international and domestic students, 23 out of the 45 students agreed, but only one agreed strongly.

When asked if teachers made a special effort to encourage international students, 28 agreed that this was happening, but barely more than half felt that teachers really understood the problems of international students.

\section{Conclusion}

Despite a lack of empirical research, there seems little doubt that international students bring a wealth of positive educational and social influences to New Zealand secondary schools, and their presence has enhanced the global "flavour" of many schools. The effect of exposing domestic "kiwi" students to knowledge about those different from themselves seems to enrich the day-to-day experiences of our young people. Nevertheless, the argument cannot be ignored that, by its policy changes, the government has encouraged schools to make money at the expense of educating domestic New Zealand students.

Some schools are now well organised with the resources they provide for meeting the needs of all students. However, many schools joining the international market are often lacking in space, language support and unity between staff and students. The Minister of Education, Trevor Mallard, admits that "New Zealand schools are pushing right to the limit of their capacity to maintain quality education standards for their students. Clearly there are limits to it" (Gamble \& Reid, 2002, p. B3).

There is every indication that many schools have gone beyond the point where the international fund is simply used to top up their operations budgets, and now rely on this funding for the day-to-day education of domestic students. It is possible that the major reason why the government has not regulated the education market place is that economically, international students are subsidising education in a major way, and will continue to do so.

In support of the findings by the Education Review Office (2003), many of the domestic and international students indicated that they had formed an international "friendship" and both groups gave similar reasons why the friendship had or had not occurred. Nevertheless, it would appear that these friendships require promotion from the teachers and the school, as indicated by Ward (2001). Further, threequarters of the domestic students indicated that the international students provided them with a chance to learn about other cultures. That must be encouraging.

The results of the case study and literature review indicate that the international students' presence in the secondary school is at some cost. Two thirds of domestic students felt that the teacher was spending too much time with the international students during the class, indicating that in some classes the demands of international students could well have changed the focus of the lesson. This is an important finding that needs examination by further empirical study on larger samples.

If the education of increasing numbers of international students is impacting adversely on domestic students, then the government has a responsibility to regulate and monitor the industry more closely. This increased monitoring can only enhance the learning experiences for 
both the international and domestic students, thereby ensuring both groups experience the maximum chance for success within the New Zealand system.

We must learn to not only tolerate our differences. We must welcome them as a richness and diversity which can lead to true intelligence.

$$
\text { (Albert Einstein) }
$$

\section{References}

Allen, S. (2004, January 28). Education boosts economy. The Dominion, p. A15.

Aston, B. (1996). Students from Asia in New Zealand secondary schools. Unpublished manuscript.

Back, K., Davis, D., \& Olsen, A. (1998). Internationalisation and tertiary education in New Zealand. Wellington: Ministry of Education.

Banks, J. (2001). Cultural diversity and education. Sydney: Allyn and Bacon.

Barber, E., \& Morgan, R. (1988). Boon or bane: Foreign graduate students in the U.S. engineering programmes. New York: Institute of Education.

Bennett, N. (1998). Asian students in New Zealand. Wellington: The Printing Press.

Bridges, D., \& McLaughlin, T. (1994). Education and the market place. London: Falmer Press.

Codd, J. (1997). NZQA and the economic rationalisation of education. Access: Critical Perspectives on Cultural and Policy Studies in Education, 16(2), 1-13.

Department of Education. (1988a). Administering for excellence: Effective administration in education (Picot Report). Wellington: Government Printer.

Department of Education. (1988b). Tomorrow's Schools: The reform of education administration in New Zealand. Wellington: Government Printer.

Education Gazette. (2002, February 11). International Business.

Education New Zealand. (2001). Annual Report - Education New Zealand Trust. Wellington: Education New Zealand.
Education New Zealand. (2002). International Education Conference Papers. Wellington: Education New Zealand.

Education New Zealand Trust. (2002). Five steps forward activity guide 2003. Wellington: New Zealand Trade Development Board.

Education Review Office. (2003). Foreign fee-paying students in New Zealand schools. Wellington: ERO.

Education Wellington International. (2003). Annual Report. Wellington: Education Wellington International.

Fiske, E., \& Ladd, H. (2000). When schools compete: A cautionary tale. Virginia: Donnelley and Sons.

Gamble, W., \& Reid, G. (2002, May 18). Lessons in foreign exchange. Weekend Herald, pp. B1-B3.

Kennedy, S. (1995). Developing a curriculum guarantee for overseas students. Higher Education Research and Development, 14, 35-46.

Kennedy, S., \& Dewars, S. (1997). Non-English speaking background students: A study of programmes and support in New Zealand. Wellington: Ministry of Education, Research and International Section.

Ministry of Education. (1995). Promoting positive race relations in New Zealand schools. Wellington: Learning Media.

Ministry of Education. (1997). Non-English speaking background students. Wellington: Learning Media.

Ministry of Education. (2001b). Export education in New Zealand: A strategic approach to developing the sector. Wellington: Ministry of Education, International Policy and Development Unit.

Ministry of Education. (2002a). Code of practice for the pastoral care of international students. Wellington: Ministry of Education, International Policy and Development Unit.

Ministry of Education. (2002b). Foreign fee-paying students in New Zealand: Statistics to 2001. Wellington: Ministry of Education, International Policy and Development Unit.

Ministry of Education. (2003). Report on research into the circumstances of very young international students in New Zealand. Wellington: Ministry of Education, International Policy and Development Unit.

New Zealand International Education Marketing Network. (2000). Economic impact analysis of foreign fee-paying students. New Zealand: Asia 2000 Foundation. 
Office of the Minister of Education. (1988, August 7). Media briefing. Wellington: Ministry of Education.

Olssen, M., \& Morris Matthews, K. (Eds.). (1997). Education policy in New Zealand: The 1990's and beyond. Palmerston North: Dunmore Press.

Ross, T. (2002, May 2). Foreign fees: Education in jeopardy. The Press, p. 9.

Stewart, D. (1993). Immigration and education. Canada: Macmillan.

Sullivan, K. (1999). Teacher standards and professionalism: Contested perspectives in a decade of reform. The New Zealand Journal of Educational Studies: Special Education. A Decade of Reform in New Zealand: Where to Now? 34(1), 144-155.

Ward, C. (2001). The impact of international students on domestic students and host institutions. Export Education Policy Project. Wellington: Ministry of Education.

\section{The author}

Deb King is the Dean of international students at Newlands College in Wellington. She is currently completing a Masters of Education degree at Victoria University. 